\section{$\mathrm{UH}$}

îi Universität Hamburg

DER FORSCHUNG I DER LEHRE । DER BILDUNG
Faculty of Business, Economics and Social Sciences

Chair for Economic Policy

FRANZISKA K. KRUSE / WOLFGANG MAENNIG

\title{
THE FUTURE DEVELOPMENT OF WORLD RECORDS
}
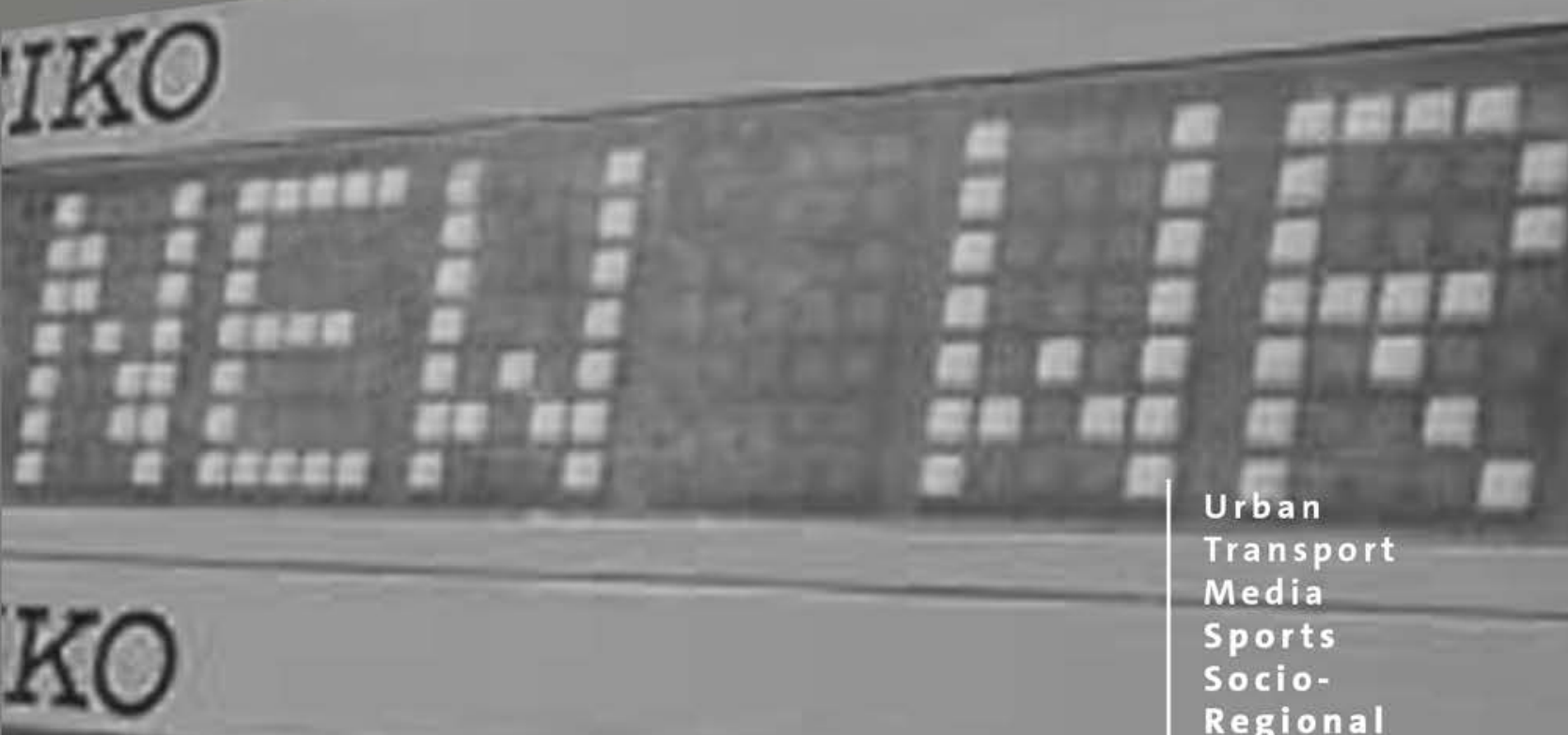

Transport

Media

Sports

Socio-

Regional

Real Estate

Architectural

HAMBURG CONTEMPORARY

ECONOMIC DISCUSSIONS

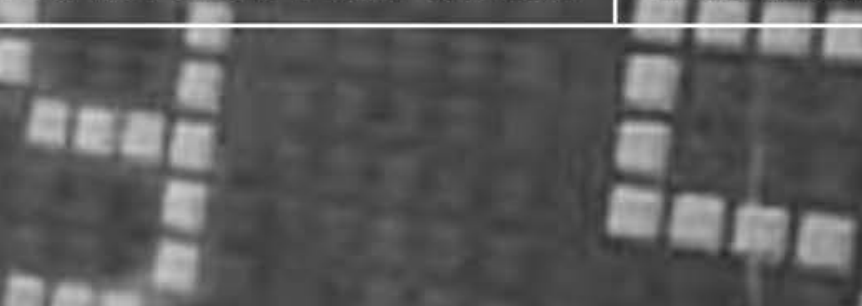

ent

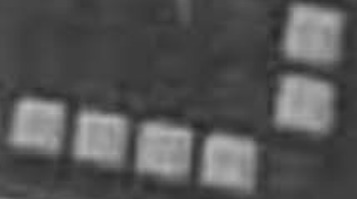

NO. 61

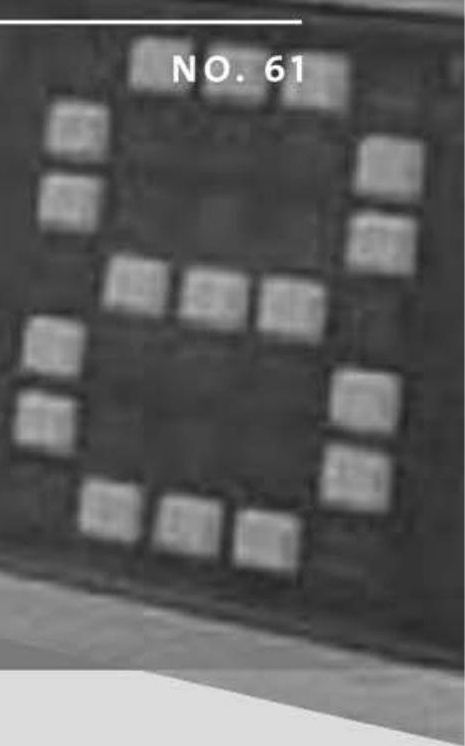




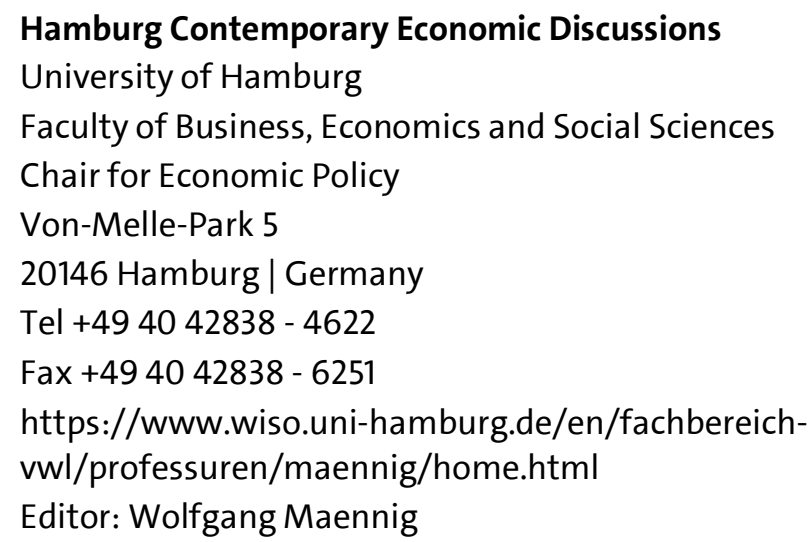

Franziska K. Kruse

University of Hamburg

Faculty of Business, Economics and Social Sciences

Chair for Economic Policy

Von-Melle-Park 5

20146 Hamburg | Germany

Tel +49 $4042838-4628$

Fax $+494042838-6251$

franziska.kruse@wiso.uni-hamburg.de

Wolfgang Maennig

University of Hamburg

Faculty of Business, Economics and Social Sciences

Chair for Economic Policy

Von-Melle-Park 5

20146 Hamburg | Germany

Tel +4940 42838 - 4622

Fax +494042838 - 6251

wolfgang.maennig@wiso.uni-hamburg.de

ISSN 1865 - 2441 (Print)

ISSN 1865 - 7133 (Online)

ISBN 978-3-942820-36-3 (Print)

ISBN 978-3-942820-37-0 (Online) 


\title{
Franziska K. Kruse, Wolfgang Maennig
}

\section{The future development of world records}

\begin{abstract}
We conduct an innovative analysis of sporting world records by a) using economic instead of sporting determinants and $b$ ) by using multivariate stochastic frontier functions. Using data from 48 different disciplines between 1970 and 2014, we show that world records are close to full efficiency and therefore actual athletic frontiers. Forecasts including economic determinants imply that the dynamics of world records largely depend on the dynamics of the frontiers and their driving forces, i.e., socioeconomic developments.

Keywords: World records, productivity growth, stochastic frontier function, technical efficiency

JEL: C10, C23, C53, L83

Version: September 2017
\end{abstract}

\section{Introduction}

New world records have become less frequent (see, for example, the table of valid world records for track and field disciplines (IAAF, 2017c)). In recent decades, athletes have been fighting to break world records that were set years, if not decades, ago. It is occasionally argued that world records set in the 1990s and before may result from doping and can barely be broken by today's athletes who are under more effective doping control. ${ }^{1}$ In other words, the athletic productivity of earlier decades is mis-measured, and athletic productivity in recent times relative to earlier times is biased downward.

However, parallel to this athletic stagnation, economic productivity growth in leading countries decreased significantly in recent decades. In the US/GB/Germany, average productivity growth was at $+2.7 \% / 2.5 \% / 1.6 \%$, respectively, from 2000 to 2007 and

\footnotetext{
${ }^{1}$ The International Association of Athletics Federations, IAAF, decided to scrap the existing world records that were achieved before 2005 and start over with new, and "clean", world records, IAAF (2017a)).
} 
decreased to $+1.1 \% / 1.2 \% /+1.3 \%$, respectively, from 2008 to $2017 .^{2}$ There is, as with athletics, a discussion of the measurement problems of economic productivity. ${ }^{3}$

Economic and productivity growth have been investigated for many decades, including the pioneering contributions of (Solow, 1956), (Romer, 1986) and (Lucas, 1988). Nearly all empirical studies find real GDP, population growth, and trade openness to be significant determinants of economic growth and productivity growth (e.g., (Afonso \& Jalles, 2013), (Danquah, Moral-Benito, \& Outtara, 2014), (Barro, 1991) and (Miller \& Upadhyay, 2000)).

Note that similar determinants were also found to be of significance for Olympic medal rankings. Publications as early as those of (Jokl, 1964), (Grimes, Kelly, \& Rubin, 1974) as well as more recent ones such as (Bernard \& Busse, 2004), (Johnson \& Ali, 2004), and (Forrest, Sanz, \& Tena, 2010) find that GDP per capita and population size impact Olympic sporting success. A larger population implies a larger pool of talents, and larger real GDP per capita may imply larger funds for the support of athletes, both facilitating better athletic achievements.

This paper analyzes world record developments on the broadest available basis of sporting disciplines and contributes to the world record literature as it begins from the assumption that economic productivity growth and that world record developments are driven by similar determinants. Earlier contributions on world records such as that by (Kuper \& Sterken, 2007), (Hanly, Sharp, \& Friskin, 2012), (Péronnet \& Thibault, 1985) and (Volf, 2011) focus on the functional (model) form and the statistical distributions of modeling world records or use determinants such as population size (Haake, Foster, \& James, 2014). Conversely, (Chang \& Baek, 2011) analyze the remaining time in years for world records to encounter a limit; however, none of these contributions include

\footnotetext{
${ }^{2}$ Data were retrieved from the US Bureau of Labor Statistics (U.S. Bureau of Labor Statistics (2017), OECD Database (OECD (2017)) and Statistisches Bundesamt (2017)).

${ }^{3}$ It has been noted that this may be a mismeasurement problem, particularly an underestimation of productivity growth in the computer industry (Byrne, Fernald, and Reinsdorf (2016)). To capture the various and, in several cases, unobservable aspects of productivity, different productivity indices were introduced, see Malmquist (1953)) and Moorsteen (1961)).
} 
economic determinants to explain the progression of world records. We forecast world records conditional on economic variables and find that world records are close to efficiency frontiers, unless new technologies may enter the picture.

Section 2 describes the data and the empirical strategy. Section 3 presents the results of our frontier approach and discusses our forecasts. Section 4 concludes.

\section{Data and empirical strategy}

We collected a database of world records for all disciplines, using official world record websites (International Association of Athletics Federations ((IAAF, 2017b), Fédération Internationale de natation (FINA, 2017), International Skating Union ((ISU, 2017) and Union Cycliste Internationale (UCI, 2017)) and measuring world records by time in seconds. A discipline was dismissed if there was no officially validated world record (e.g., triathlon). We restricted the sample to $1970-2014$, due to the availability of control variables, and excluded disciplines that experienced significant changes in regulations. For disciplines with both indoor and outdoor records, we focus on the indoor records. Swimming data are obtained from the Olympic long course (50 meters) data set, which is historically older than the short track (25 meters). The full list of disciplines is displayed in Table A1. The list includes 19 disciplines in running, two disciplines in walking, 17 different kinds of swimming disciplines, six speed skating disciplines and four track cycling disciplines. If the records showed various observations for one discipline in one year, in other words, when the world record was renewed more than one time in a year, we used the fastest of all the observations in that year.

We collected data for women's and men's world records. However, since the variance in women's records is small and the women's world records include fewer data points, a stochastic frontier analysis did not converge. Therefore, we needed to restrict ourselves to the analysis of men's world records. 
For the selection of control variables, we utilize the insights of the literature of economic growth and use yearly data of GDP per capita, population and exports (in \% of GDP) ((Barro, 1991), (Baltabaev, 2014), (Afonso \& Jalles, 2013) and (Danquah et al., 2014)). Data for the real GDP per capita were collected from the World Penn Tables 9.0 (Feenstra, Inklaar, \& Timmer, 2015)). Data for exports and population were taken from the World Bank Data Bank (World Bank, 2017)). The aggregates are calculated from the data of 13 of the 15 with the largest medal success in the Summer and Winter Games 2002-2016, winning $73 \%$ of all gold medals (Table A2 in the appendix). Russia and the Ukraine needed to be excluded as no complete economic data sets were available.

The descriptive statistics for the control variables are represented in table 1 and figure 1.

Table 1 Descriptive statistics of control variables

\begin{tabular}{lccccc}
\hline Variable & Observations & Mean & $\begin{array}{l}\text { Standard } \\
\text { Deviation }\end{array}$ & Minimum & Maximum \\
\hline $\begin{array}{l}\text { Exports (in \% } \\
\text { of GDP) }\end{array}$ & 45 & 17.87 & 3.44 & 12.10 & 24.85 \\
$\begin{array}{l}\text { Population } \\
\text { Real GDP per }\end{array}$ & 45 & $1.88 e^{08}$ & $2.28 e^{08}$ & $1.46 e^{09}$ & $2.21 e^{09}$ \\
Capita & 45 & $12,739.32$ & $2,846.13$ & $8,149.18$ & $17,034.06$ \\
\hline
\end{tabular}

Sources: Data basis: World Bank (2017), Center for International Comparisons at the University of Pennsylvania (CICUP, 2006); own calculations. 
Figure 1 The dynamics of control variables


Note: Figure 1 and table 1 display the descriptive statistics of three time series of control variables used in the empirical analysis. Exports are provided in \% of GDP. Population and real GDP per capita are absolute numbers.

We estimate a true random effects stochastic frontier model for panel data ((Aigner, Lovell, \& Schmidt, 1977), (Greene, 2005)). This model is used when the data are panel data and when the constant can be assumed to be random. In accordance with (Fair, 1994) and (Maennig \& Stobernack, 2011), we include all dependent and independent variables as natural logs in the analysis (except year and year ${ }^{2}$ ). In order to connect our analysis to earlier studies such as size (Haake et al., 2014), we start by regressing the natural logarithm of the world record times (in seconds) on year and year ${ }^{2}$ (normalizing the years to $1970=1$ ), as well as the natural logarithm of population. The inclusion of the additional control variables in the equation leads to a multicollinearity problem that is displayed in the variance-covariance-matrix of the estimates in table A3. Since real GDP per capita and the year variables are highly collinear, ${ }^{4}$ we excluded the year variables for

\footnotetext{
${ }^{4}$ The augmented Dickey-Fuller-Test suggests that all our control variables are stationary with a trend.
} 
further analyses. In addition, real GDP per capita and population are highly collinear. Therefore, we first include population in the analysis to confirm the "negative" impact of population from the earlier contributions noted above. Thereafter, we dismiss population and include our economic variables. The estimation equations read as follows:

$$
\begin{gathered}
\text { M1: } \ln (\text { time })_{i t}=\left(\alpha_{0}+\omega_{i}\right)+\beta_{1} \ln (\text { population })_{i t}+\varepsilon_{i t} \\
M 2: \ln (\text { time })=\left(\alpha_{0}+\omega_{i}\right)+\beta_{1} \ln (\text { real GDP per capita })_{i t} \\
M 3: \ln (\text { time })=\left(\alpha_{0}+\omega_{i}\right)+\beta_{1} \ln (\text { real GDP per capita })_{i t}+\beta_{2} \ln (\text { exports }),
\end{gathered}
$$

all specifications with

$$
\begin{gathered}
\varepsilon_{i t}=v_{i t}-u_{i t}, i=1, \ldots N, \\
u_{i t} \sim \mathbb{N}^{+}\left(0 ; \sigma_{i t}^{2}\right)=\mathbb{N}^{+}\left(0, \exp \left(\omega_{u 0}+z_{u, i t}^{\prime} \omega_{u}\right)\right), \\
v_{i t} \sim \mathbb{N}\left(0, \sigma_{v}^{2}\right), \\
\omega_{i} \sim \mathbb{N}\left(0, \sigma_{\omega}^{2}\right),
\end{gathered}
$$

This symmetric normal and half-normal distribution of the error terms helps to define the frontier in an appropriate manner (Aigner et al., 1977)). (Greene, 2005) focuses on the modeling of the inefficiency that can be calculated from the model to overhaul the shortcomings of the original model of (Aigner et al., 1977), since, in this specification, the mean and variance of $u_{i t}$ can depend on variables that are time-invariant. The constant is also treated as random in this model (Greene, 2005), (Kumbhakar, Lien, \& Hardaker, 2012)).

\section{World record developments, 1970-2014: Results and discussion}

Column 2 in Table 2 displays the results with $\ln$ (population) as only explanatory variable. In further steps, we test the log of real GDP per capita (column 3) as well as the logarithm 
of exports (in \% of GDP) (column 4). The conduction of each analysis includes 10,000 pseudo random draws. ${ }^{5}$

Table 2 World records; stochastic frontier estimates

\begin{tabular}{llll}
\hline Ln(time) & Model 1 (M1) & Model 2 (M2) & Model 3 (M3) \\
\hline Constant & $12.10835^{\star \star \star}$ & $10.6563^{\star \star \star}$ & $9.339705^{\star \star \star}$ \\
In(population) & $(.0541974)$ & $(.0173155)$ & $(.0245242)$ \\
Ln(real GDP per capita) & $\left(.206544^{\star \star \star}\right.$ & & $-.1044162^{\star \star \star}$ \\
Ln(exports) & & $-.1119436^{\star \star \star}$ & $(.0037256)$ \\
Number of observations & 2068 & $(.0017988)$ & $-.0073345^{\star}$ \\
& & 2068 & $(.0045232)$ \\
Number of groups & 48 & & 2068 \\
Log simulated likelihood & 5047.2641 & 48 & 48 \\
Wald Chi & & 4962.8966 & 5061.6737 \\
Prob > Chi & & 3872.82 & 4133.85 \\
& 6659.78 & 0.0000 & 0.0000 \\
AlC & 0.0000 & -9915.793 & -10111.35 \\
BIC & $-10,084.53$ & -9887.621 & -10077.54 \\
\hline
\end{tabular}

Standard errors are in parentheses. ${ }^{* * *} / * * * *$ significant at the $1 / 5 / 10 \%$ level, respectively.

According to the Akaike and Bayesian information criteria, the model specification M2 has the lowest information quality compared to the other models. Information criteria for $M 1$ and $M 3$ are within the same range. Since we focus on economic and not demographic variables, we choose M3 as the preferred model specification. The Waldtest, with its p-value, suggests that at least one coefficient is not equal to zero in each model specification, and that that the models are (highly) significant.

In model specification M1, we replicate the results of (Haake et al., 2014) by confirming the "negative" impact of population on world record times. If the population is growing, the pool of talents is growing, implying a larger likelihood that world records may be broken. In M2, we include real GDP per capita exclusively, due to the issues noted above.

\footnotetext{
${ }^{5}$ The results are robust to an increase in draws.
} 
In this model specification as well as in M3, real GDP per capita does have a significantly negative coefficient in all models, implying a positive impact on athletic performance. In the last specification, we add exports. The estimated coefficient is significantly negative (on a 10*-level); higher exports represent a higher degree of openness of countries trading new technologies and knowledge between each other. This exchange can positively influence the world record times attained, since athletes may be able to use these traded goods to improve their performance.

On the basis of model specification M3, we calculated the technical efficiency of the world record of each discipline according to the frontier analysis. The progress of the estimated technical efficiencies of the selected disciplines is displayed in figure 2 , in \% of athletic-technological frontiers.

Figure 2 Technical efficiency of selected disciplines, in \% of technical frontiers
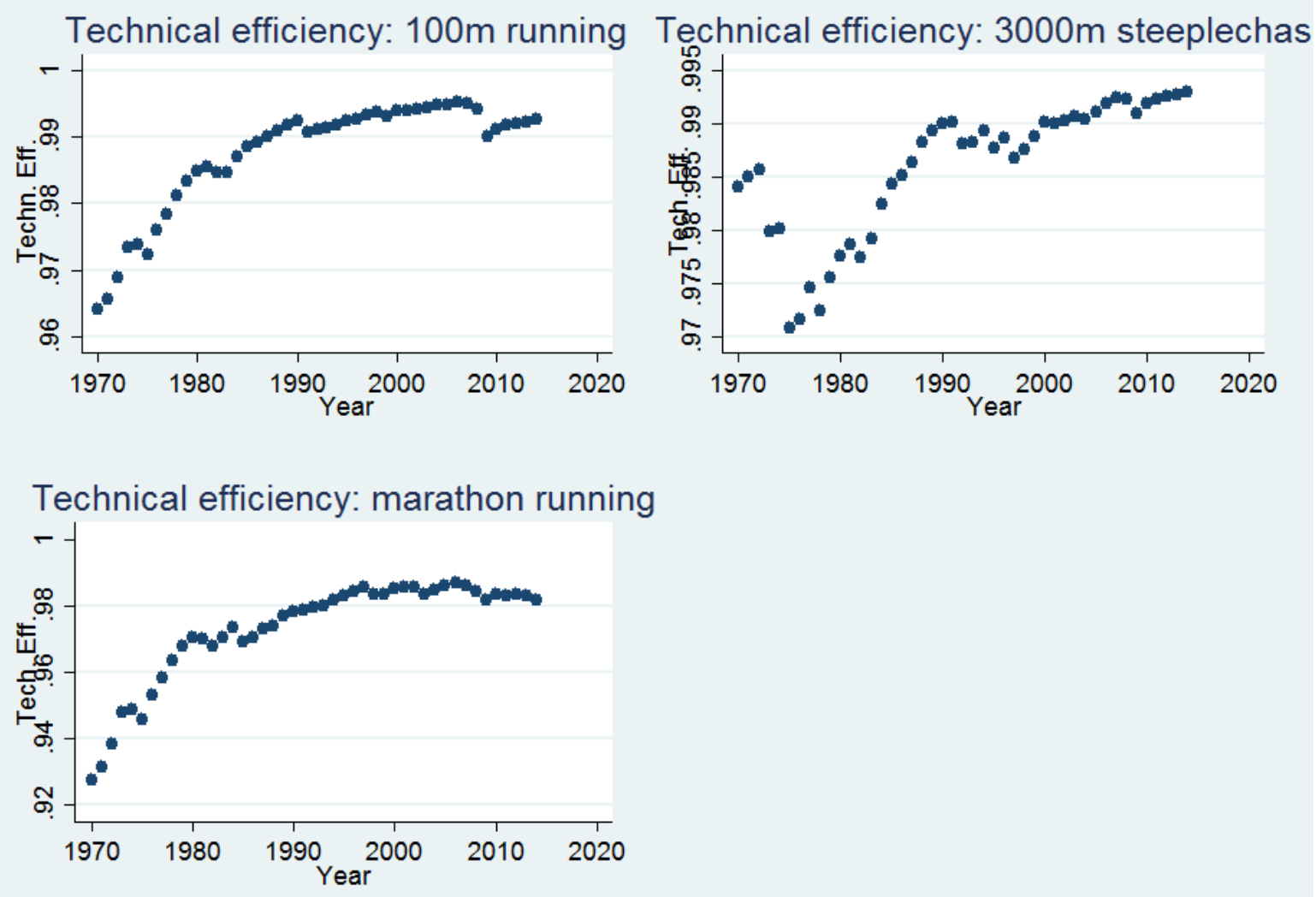
The graphical illustration emphasizes that certain disciplines are close to their current frontier (the technical efficiency of the 100-m dash and marathon are currently at 0.992/0.981, respectively, in 2014). A technical efficiency of 1 (or near one) indicates that world records are very near or are at the frontier.

\section{Forecasting world records}

Next, we perform out-of-sample forecasting for the regressors and the dependent variable. Since the real GDP per capita, population and exports (in \% of GDP) are showing an upward trend in the data, we used the non-seasonal Holt-Winter forecasting method ((Winters, 1960), (Chatfield, 1978), among others). We transformed the forecasted variables in the same manner as in the first analysis to forecast new world record times and the technical efficiency.

We could not forecast several disciplines since their estimations did not converge (potentially due to minimal variance in the data). For the remaining disciplines, a point forecast was estimated for 2022 (table 3). Our starting point in 2014 is the existing world record. 
Table 3 Out-of-sample forecasting and technical efficiency for selected disciplines

\begin{tabular}{|c|c|c|c|c|c|c|c|}
\hline Discipline & Constant & $\begin{array}{l}\text { Ln(real GDP } \\
\text { per capita) }\end{array}$ & Ln(exports) & $\begin{array}{l}\text { Time (in } \\
\text { seconds) } \\
2014\end{array}$ & $\begin{array}{l}\text { Technical } \\
\text { Efficiency }\end{array}$ & $\begin{array}{l}\text { Forecasted } \\
\text { time in } \\
2022\end{array}$ & $\begin{array}{l}\text { Technical } \\
\text { Efficiency }\end{array}$ \\
\hline $\begin{array}{l}\text { Running } \\
100 \mathrm{~m}\end{array}$ & $\begin{array}{l}2.609316^{\star \star \star} \\
(6.16 \mathrm{e}-06)\end{array}$ & $\begin{array}{l}-0.025522^{\star \star \star} \\
(9.06 \mathrm{e}-07)\end{array}$ & $\begin{array}{l}-0.026705^{\star \star \star} \\
(1.34 \mathrm{e}-06)\end{array}$ & 9.58 & .9856839 & 9.56 & 0.9947168 \\
\hline $\begin{array}{l}\text { Running } \\
1 \text { Mile }\end{array}$ & $\begin{array}{l}5.959913^{\star \star \star} \\
(.0291422)\end{array}$ & $\begin{array}{l}-.0590554^{\star \star \star} \\
(.0041037)\end{array}$ & $\begin{array}{l}.007191^{\star} \\
(.0042049)\end{array}$ & 223.13 & .998641 & 222.07 & .9988881 \\
\hline $\begin{array}{l}\text { 3000-m } \\
\text { steeplechase }\end{array}$ & $\begin{array}{l}6.674914^{\star \star \star} \\
(.0464893)\end{array}$ & $\begin{array}{l}-.0430587^{\star \star \star} \\
(.0071878)\end{array}$ & $\begin{array}{l}-.0316784^{\star \star \star} \\
(.0087717)\end{array}$ & 473.63 & .9999 & 467.87 & .999907 \\
\hline 400-m hurdles & $\begin{array}{l}4.186533^{\star \star \star} \\
(.0380824)\end{array}$ & $\begin{array}{l}-.0377411^{\star \star \star} \\
(.0058674)\end{array}$ & $\begin{array}{l}.0072792 \\
(.0071603)\end{array}$ & 46.78 & .9999081 & 46.48 & .999907 \\
\hline $\begin{array}{l}\text { Speed Skating } \\
1500 \mathrm{~m}\end{array}$ & $\begin{array}{l}6.807781 \text { *** } \\
(.1305647)\end{array}$ & $\begin{array}{l}-.1912672^{\star \star \star} \\
(.0202)\end{array}$ & $\begin{array}{l}-.1045627^{\star \star \star} \\
(.0246512)\end{array}$ & 101.04 & .9997429 & 98.08 & .9997402 \\
\hline $\begin{array}{l}\text { Swimming } \\
800-m \text { freestyle }\end{array}$ & $\begin{array}{l}7.085062^{\star \star \star} \\
(.1020592)\end{array}$ & $\begin{array}{l}-.0838685^{\star \star \star} \\
(.0157984)\end{array}$ & $\begin{array}{l}-.0491433^{\star \star \star} \\
(.0192798)\end{array}$ & 452.12 & .999814 & 445.86 & .999814 \\
\hline $\begin{array}{l}\text { Swimming } \\
50-\mathrm{m} \text { backstroke }\end{array}$ & $\begin{array}{l}3.327085^{\star \star \star} \\
(.0985235)\end{array}$ & $\begin{array}{l}.0356222^{\star *} \\
(.0149812)\end{array}$ & $\begin{array}{l}-.1278487^{\star \star \star} \\
(.0004963)\end{array}$ & 24.04 & 991375 & 23.97 & 0.995074 \\
\hline
\end{tabular}

Note: Standard errors are in parentheses. ${ }^{* * *} /{ }^{* *} /{ }^{*}=$ significant at the $1 / 5 / 10 \%$ level, respectively.

According to Tab. 3, world records of the 1-mile run, 3000-m steeplechase, and 50-m backstroke swimming may further approach the technical efficiency limits of 1 until 2022, indicating a reduced potential for world record improvements beyond the general economic growth as long as no extraordinary technical change (e.g., doping or a major reformation in technologies) arise. This finding is outstanding for the 3000-m steeplechase, which had a high technical efficiency previously in 2014. For the 100-m dash, 400-m hurdles, and 1500-m speed skating, our forecasts imply new world records but a decreasing technical efficiency. Thus, the shift of the frontier is forecasted to be larger than the dynamics of the world records. ${ }^{6}$

\footnotetext{
${ }^{6}$ For the $400 \mathrm{~m}$ hurdles running, we find that the coefficient for exports is not significant. For our forecast of future world records, we neglected such non-significant variables.
} 
We forecast the largest improvement for world records for speed skating (improvement of world record time of $2.92 \%$ until 2022). The least dynamic discipline, the $100-\mathrm{m}$ dash, enjoys a forecasted improvement of $0.2 \%$ of the world record time.

\section{Conclusion}

We conduct an innovative analysis and forecast athletic world records by using economic variables and demonstrated that athletic and economic productivity are driven by similar determinants, also implying potential parallels in their future developments. We show that most current world records are close to their technological/ athletic frontier. World record improvements will largely depend on the extent of the growth in technical frontiers, i.e., of determinants that drive economic growth as well. If those determinants only display a limited dynamic (as is suggested by the economic growth literature and by our forecasts), a slowing of the dynamic of world records may be expected as well.

There are certain caveats. If there are major technological changes and hidden abuses of medical and pharmaceutical progress that are not in accordance with general economic progress, such as a revolution in the bikes for track cycling, our result may be biased downward.

There is one more insight from our analysis that may motivate further research: The low rates of economic productivity growth in Western economies in recent years are less surprising if contrasted with athletic developments. 


\section{References}

Afonso, A., \& Jalles, J. T. (2013). Growth and productivity - The role of government debt. International Review of Economics and Finance, 25, 384-407.

Aigner, D., Lovell, C. K., \& Schmidt, P. (1977). Formulation and estimation of stochastic frontier production function models. Journal of Econometrics, 6, 21-37.

Baltabaev, B. (2014). Foreign Direct Investment and Total Factor Productivity growth: New Macro-Evidence. The World Economy, 37(2), 311-334.

Barro, R. J. (1991). Economic Growth in a Cross Section of Countries. The Quarterly Journal of Economics, 106(2), 407-443.

Bernard, A. B., \& Busse, M. R. (2004). Who wins the Olympic Games: economic resources and medal totals. The Review of Economics and Statistics, 86(1), 413-417.

Byrne, D. M., Fernald, J. G., \& Reinsdorf, M. B. (2016). Does the United States Have a Productivity Slowdown or a Measurement Problem? Brookings Papers on Economic Activity, Spring, 109-157.

Center for International Comparisons at the University of Pennsylvania (CICUP). (2006). The Penn World Table. Retrieved from http://pwt.econ.upenn.edu/aboutpwt2.html

Chang, Y. S., \& Baek, S. J. (2011). Limit to improvement in running and swimming. International Journal of Applied Management Science, 3(1), 97-120.

Chatfield, C. (1978). The Holt-Winters Forecasting Procedure. Journal of Royal Statistical Society. Series C (Applied Statistics), 27(3), 264-279.

Danquah, M., Moral-Benito, E., \& Outtara, B. (2014). TFP Growth and its determinants: nonparametrics and model averaging. Empirical Economics, 47(1), 227-251.

Fair, R. C. (1994). How Fast Do Old Men Slow Down? The Review of Economics and Statistics, 76(1), 103-118.

Feenstra, R. C., Inklaar, R., \& Timmer, M. P. (2015). The Next Generation of the Penn World Table. American Economic Review, 105(10), 3150-3182.

FINA. (2017). Swimming records. Retrieved from http://www.fina.org/content/ swimming-records 
Forrest, D., Sanz, I., \& Tena, J. D. (2010). Forecasting national team mdel totals at the Summer Olympic Games. International Journal of Forecasting, 26, 576-588.

Greene, W. (2005). Fixed and random effects in stochastic frontier models. Journal of Productivity Analysis, 23(1), 7-32.

Grimes, R. A., Kelly, W. J., \& Rubin, P. H. (1974). A socioeconomic model of national olympic performance. Social Science Quarterly, 55(3), 777-783.

Haake, S. J., Foster, L. I., \& James, D. M. (2014). An improvement index to quantify the evolution of performance in running. Journal of Sports Sciences, 32(7), 610-622.

Hanly, E., Sharp, G., \& Friskin, D. (2012). Modelling track records using compound distributions. Annual Proceedings of the South African Statistical Association Conference, 1, 50-57.

IAAF. (2017a). European Athletics endorses record 'revolution' plan. Retrieved from https://www.iaaf.org/news/news/european-athletics-records-plan

IAAF. (2017b). Records and lists. Retrieved from https://www.iaaf.org/records/ toplists/sprints/100-metres/outdoor/men/senior/2017

IAAF. (2017c). World Records. Retrieved from https://www.iaaf.org/records/by-category/world-records

ISU. (2017). Biographies and Statistics. Retrieved from http://www.isu.org/inside-speedskating/entries-results-speed/biographiesstatistics\#PageID\%3D103004\&SportID\%3D103\&SeasonID\%3D-1\&ClassID\%3D1\&GenderID\%3D1\&TaalCode\%3D2\&StyleID\%3D0\&Cache\%3D2.html?967998

Johnson, D. K., \& Ali, A. (2004). A Tale of Two Seasons: Participation and Medal Counts at the Summer and Winter Olympic Games. Social Science Quarterly, 55(3), 974-993. Jokl, E. (1964). Health, wealth and athletics. In E. Jokl (Ed.), International Research in sport and physical education (pp. 218-222). Springfield.

Kumbhakar, S. C., Lien, G., \& Hardaker, J. B. (2012). Technical efficiency in ceompting panel data models: a study of Norwegian grain farming. Journal of Productivity Analysis. Retrieved from DOI: 10.1007/s11123-012-0303-1 
Kuper, G., \& Sterken, E. (2007). Modelling the development of world records in running. In J. Albert \& R. H. Koning (Eds.), Statistical Thinking in Sports (pp. 7-32). Boca Raton: CRC Press.

Lucas, R. E., JR. (1988). On the Mechanics of Economic Development. Journal of Monetary Economics, 22(1), 3-42.

Maennig, W., \& Stobernack, M. (2011). Do men slow down faster than women? Review of Economics, 62(3), 263-278.

Malmquist, S. (1953). Index numbers and indifference surfaces. Trabajos de Estadistica, $4(2), 209-242$.

Miller, S. M., \& Upadhyay, M. P. (2000). The Effects of Openness, Trade Orientation and Human Capital on Total Factor Productivity. Journal of Development Economics, 63(2), 399-423.

Moorsteen, R. H. (1961). On Measuring Productive Potential and Relative Efficiency. The Quarterly Journal of Economics, 75(3), 451-467.

OECD. (2017). Growth in GDP per capita, productivity and ULC. Retrieved from http://stats.oecd.org/Index.aspx?DataSetCode=PDB_GR

Péronnet, F., \& Thibault, G. (1985). Mathematical analysis of running performance and world running records. Journal of applied physiology, 67(1), 453-465.

Romer, P. M. (1986). Increasing Returns and Long-run Growth. Journal of Political Economy, 94(4), 1002-1037.

Solow, R. M. (1956). A Contribution to the Theory of Economic Growth. The Quarterly Journal of Economics, 70(1), 65-94.

Statistisches Bundesamt. (2017). Detailed gross domestic product results for the 2nd quarter of 2017. Wiesbaden. Retrieved from https://www.destatis.de/EN/ PressServices/Press/pr/2017/08/PE17_294_811.html

U.S. Bureau of Labour Statistics. (2017). Major Sector Productivity and Costs. Retrieved from https://data.bls.gov/cgi-bin/surveymost 
UCl. (2017). World records. Retrieved from http://www.uci.ch/track/news/article/ world-records/

Volf, P. (2011). A stochastic model of progression of athletic records. IMA Journal of Management Mathematics, 22, 157-169.

Winters, P. R. (1960). Forecasting Sales by Exponentially Weighted Moving Averages. Management Science, 6(3), 324-342.

World Bank. (2017). Data Bank. Retrieved from http://databank.worldbank.org/data/ home.aspx 


\section{Appendix}

Table A1 Disciplines with sound world records included in our analysis

\begin{tabular}{|c|c|}
\hline Running & Track cycling \\
\hline \multicolumn{2}{|l|}{$60 \mathrm{~m}$} \\
\hline $100 \mathrm{~m}$ & $200 \mathrm{~m}$ \\
\hline $200 \mathrm{~m}$ & $500 \mathrm{~m}$ \\
\hline $400 \mathrm{~m}$ & $1000 \mathrm{~m}$ \\
\hline $800 \mathrm{~m}$ & $4000 \mathrm{~m}$ \\
\hline \multicolumn{2}{|l|}{$1000 \mathrm{~m}$} \\
\hline \multicolumn{2}{|l|}{$1500 \mathrm{~m}$} \\
\hline \multicolumn{2}{|l|}{1 mile } \\
\hline \multicolumn{2}{|l|}{$3000 \mathrm{~m}$} \\
\hline \multicolumn{2}{|c|}{ 3000-m steeplechase } \\
\hline \multicolumn{2}{|l|}{2 miles } \\
\hline \multicolumn{2}{|l|}{$5000 \mathrm{~m}$} \\
\hline \multicolumn{2}{|l|}{$10,000 \mathrm{~m}$} \\
\hline \multicolumn{2}{|l|}{$21.1 \mathrm{~km}$} \\
\hline \multicolumn{2}{|l|}{$42.2 \mathrm{~km}$} \\
\hline \multicolumn{2}{|l|}{ 110-m Hurdles } \\
\hline \multicolumn{2}{|l|}{ 400-m Hurdles } \\
\hline \multicolumn{2}{|l|}{ 4x100-m relay } \\
\hline \multicolumn{2}{|l|}{ 4x400-m relay } \\
\hline \multicolumn{2}{|l|}{ 20-km walking } \\
\hline \multicolumn{2}{|l|}{ 50-km walking } \\
\hline Swimming & Speed skating \\
\hline 50-m freestyle & $500 \mathrm{~m}$ \\
\hline 100-m freestyle & $1000 \mathrm{~m}$ \\
\hline 200-m freestyle & $1500 \mathrm{~m}$ \\
\hline 400-m freestyle & $3000 \mathrm{~m}$ \\
\hline 800-m freestyle & $5000 \mathrm{~m}$ \\
\hline 1500-m freestyle & $10000 \mathrm{~m}$ \\
\hline \multicolumn{2}{|l|}{ 50-m backstroke } \\
\hline \multicolumn{2}{|l|}{ 100-m backstroke } \\
\hline \multicolumn{2}{|l|}{ 200-m backstroke } \\
\hline \multicolumn{2}{|c|}{ 50-m breast stroke } \\
\hline \multicolumn{2}{|c|}{$100-m$ breast stroke } \\
\hline \multicolumn{2}{|c|}{ 200-m breast stroke } \\
\hline \multicolumn{2}{|c|}{ 50-m butterfly } \\
\hline \multicolumn{2}{|l|}{ 100-m butterfly } \\
\hline \multicolumn{2}{|l|}{ 200-m butterfly } \\
\hline \multicolumn{2}{|l|}{$4 \times 100-m$ relay } \\
\hline 4x200-m relay & \\
\hline
\end{tabular}


Table A2 Proportions of gold, silver and bronze medals won in all (Summer and Winter) Games from 2002-2016 per country

\begin{tabular}{lcccc}
\hline $\begin{array}{l}\text { Proportions of medals in all Games } \\
\text { from 2002-2016 }\end{array}$ & Overall & Gold & Silver & Bronze \\
\hline 1. USA & $11,96 \%$ & $12,88 \%$ & $11,96 \%$ & $11,04 \%$ \\
2. Russia & $8,15 \%$ & $7,75 \%$ & $7,46 \%$ & $9,25 \%$ \\
3. China & $7,71 \%$ & $10,19 \%$ & $6,23 \%$ & $6,68 \%$ \\
4. Germany & $6,21 \%$ & $6,28 \%$ & $6,56 \%$ & $5,78 \%$ \\
5. UK & $4,64 \%$ & $5,58 \%$ & $4,12 \%$ & $4,24 \%$ \\
6. France & $4,20 \%$ & $3,33 \%$ & $4,37 \%$ & $4,88 \%$ \\
7. Australia & $3,64 \%$ & $3,33 \%$ & $3,86 \%$ & $3,72 \%$ \\
8. Canada & $3,49 \%$ & $3,14 \%$ & $3,41 \%$ & $3,92 \%$ \\
9. Japan & $3,36 \%$ & $2,95 \%$ & $2,89 \%$ & $4,24 \%$ \\
10. Italy & $3,25 \%$ & $2,82 \%$ & $3,08 \%$ & $3,85 \%$ \\
11. South Korea & $3,15 \%$ & $3,91 \%$ & $3,02 \%$ & $2,50 \%$ \\
12. Netherlands & $2,70 \%$ & $2,76 \%$ & $2,70 \%$ & $2,63 \%$ \\
13. Norway & $2,48 \%$ & $2,88 \%$ & $2,06 \%$ & $2,50 \%$ \\
14. Ukraine & $1,77 \%$ & $1,54 \%$ & $1,29 \%$ & $2,50 \%$ \\
15. Switzerland & $1,46 \%$ & $1,79 \%$ & $0,96 \%$ & $1,61 \%$ \\
16. Hungary & $1,28 \%$ & $1,73 \%$ & $1,16 \%$ & $0,96 \%$ \\
& $\mathbf{6 9 , 4 5 \%}$ & $\mathbf{7 2 , 8 6 \%}$ & $\mathbf{6 3 , 0 7 \%}$ & $\mathbf{7 0 , 3 \%}$ \\
\hline
\end{tabular}

Note: Sorted by the proportion of all the medals won in relation to all possible medals.

Source: $I O C$ - own calculation of proportions

Table A3 Variance covariance matrix of estimated results from model specification

\begin{tabular}{lllllll}
\hline Frontier & Year & Year $^{2}$ & Ln(population) & $\begin{array}{l}\text { Ln(real GDP } \\
\text { per capita) }\end{array}$ & Ln(exports) & Constant \\
\hline Year & 1.0000 & & & & & \\
Year & -0.7243 & 1.0000 & & & & \\
$\begin{array}{l}\text { Ln } \\
\text { (population) }\end{array}$ & 0.1570 & -0.0005 & 1.0000 & & & \\
$\begin{array}{l}\text { Ln(Real GDP } \\
\text { per capita) }\end{array}$ & -0.7063 & 0.3105 & -0.4478 & 1.0000 & & \\
$\begin{array}{l}\text { Ln(exports) } \\
\text { constant }\end{array}$ & -0.2074 & -0.2956 & -0.0981 & -0.0262 & 1.0000 & \\
\hline
\end{tabular}

Source: Own calculation of proportions 


\section{Hamburg Contemporary Economic Discussions}

(Download: https://www.wiso.uni-hamburg.de/en/fachbereich-vwl/professuren/maennig/research/hceds.html)

61

60

59

58

57

56

55

54

53

52

51

50

49

48

47

46

45

KRUSE, F. K. / MAENNIG, W.: The future development of world records, 2017.

MAENNIG, W.: Governance in Sports Organizations, 2017.

AHLFELDT, G. M. / MAENNIG, W. / FELIX J. RICHTER: Zoning in reunified Berlin, 2017.

MAENNIG, W.: Major Sports Events: Economic Impact, 2017.

MAENNIG, W.: Public Referenda and Public Opinion on Olympic Games, 2017.

MAENNIG, W. / WELLBROCK, C.: Rio 2016: Sozioökonomische Projektion des Olympischen Medaillenrankings, 2016.

MAENNIG, W. / VIERHAUS, C.: Which countries bid for the Olympic Games? Economic, political, and social factors and chances of winning, 2016.

AHLFELDT, G. M. / MAENNIG, W. / STEENBECK, M.: Après nous le déluge? Direct democracy and intergenerational conflicts in aging societies, 2016.

LANGER, V. C. E.: Good news about news shocks, 2015.

2 LANGER, V. C. E. / MAENNIG, W. / RICHTER, F. J.: News Shocks in the Data: Olympic Games and their Macroeconomic Effects - Reply, 2015.

MAENNIG, W.: Ensuring Good Governance and Preventing Corruption in the Planning of Major Sporting Events - Open Issues, 2015.

MAENNIG, W. / VIERHAUS, C.: Who Wins Olympic Bids? 2015 (3 $3^{\text {rd }}$ version).

AHLFELDT, G. M. / MAENNIG, W. / RICHTER, F.: Urban Renewal after the Berlin Wall, 2013.

BRANDT, S. / MAENNIG, W. / RICHTER, F.: Do Places of Worship Affect Housing Prices? Evidence from Germany, 2013.

ARAGÃO, T. / MAENNIG, W.: Mega Sporting Events, Real Estate, and Urban Social Economics - The Case of Brazil 2014/2016, 2013.

MAENNIG, W. / STEENBECK, M. / WILHELM, M.: Rhythms and Cycles in Happiness, 2013.

RICHTER, F. / STEENBECK, M. / WILHELM, M.: The Fukushima Accident and Policy Implications: Notes on Public Perception in Germany, 2014 (2 ${ }^{\text {nd }}$ version). 


\section{Hamburg Contemporary Economic Discussions}

(Download: https://www.wiso.uni-hamburg.de/en/fachbereich-vwl/professuren/maennig/research/hceds.html)

44

MAENNIG, W.: London 2012 - das Ende des Mythos vom erfolgreichen Sportsoldaten, 2012.

MAENNIG, W. / WELLBROCK, C.: London 2012 - Medal Projection Medaillenvorausberechnung, 2012.

MAENNIG, W. / RICHTER, F.: Exports and Olympic Games: Is there a Signal Effect? 2012.

MAENNIG, W. / WILHELM, M.: Becoming (Un)employed and Life Satisfaction: Asymmetric Effects and Potential Omitted Variable Bias in Empirical Happiness Studies, 2011.

MAENNIG, W.: Monument Protection and Zoning in Germany: Regulations and Public Support from an International Perspective, 2011.

BRANDT, S. / MAENNIG, W.: Perceived Externalities of Cell Phone Base Stations - The Case of Property Prices in Hamburg, Germany, 2011.

MAENNIG, W. / STOBERNACK, M.: Do Men Slow Down Faster than Women? 2010.

7 DU PLESSIS, S. A. / MAENNIG, W.: The 2010 World Cup High-frequency Data Economics: Effects on International Awareness and (Self-defeating) Tourism, 2010.

6 BISCHOFF, O.: Explaining Regional Variation in Equilibrium Real Estate Prices and Income, 2010.

5 FEDDERSEN, A. / MAENNIG, W.: Mega-Events and Sectoral Employment: The Case of the 1996 Olympic Games, 2010.

4 FISCHER, J.A.V. / SOUSA-POZA, A.: The Impact of Institutions on Firms Rejuvenation Policies: Early Retirement with Severance Pay versus Simple Lay-Off. A Cross-European Analysis, 2010.

FEDDERSEN, A. / MAENNIG, W.: Sectoral Labor Market Effects of the 2006 FIFA World Cup, 2010.

2 AHLFELDT, G.: Blessing or Curse? Appreciation, Amenities, and Resistance around the Berlin “Mediaspree”, 2010. 


\section{Hamburg Contemporary Economic Discussions}

(Download: https://www.wiso.uni-hamburg.de/en/fachbereich-vwl/professuren/maennig/research/hceds.html)

FALCH, T. / FISCHER, J.A.V.: Public Sector Decentralization and School Performance: International Evidence, 2010.

AHLFELDT, G. / MAENNIG, W. /ÖLSCHLÄGER, M.: Lifestyles and Preferences for (Public) Goods: Professional Football in Munich, 2009.

FEDDERSEN, A. / JACOBSEN, S. / MAENNIG, W.: Sports Heroes and Mass Sports Participation - The (Double) Paradox of the "German Tennis Boom", 2009.

AHLFELDT, G. / MAENNIG, W. / OSTERHEIDER, T.: Regional and Sectoral Effects of a Common Monetary Policy: Evidence from Euro Referenda in Denmark and Sweden, 2009.

7 BJØRNSKOV, C. /DREHER, A. /FISCHER, J.A.V. /SCHNELLENBACH, J.: On the Relation Between Income Inequality and Happiness: Do Fairness Perceptions Matter? 2009.

AHLFELDT, G. / MAENNIG, W.: Impact of Non-Smoking Ordinances on Hospitality Revenues: The Case of Germany, 2009.

FEDDERSEN, A. / MAENNIG, W.: Wage and Employment Effects of the Olympic Games in Atlanta 1996 Reconsidered, 2009.

AHLFELDT, G. / FRANKE, B. / MAENNIG, W.: Terrorism and the Regional and Religious Risk Perception of Foreigners: The Case of German Tourists, 2009.

AHLFELDT, G. / WENDLAND, N.: Fifty Years of Urban Accessibility: The Impact of Urban Railway Network on the Land Gradient in Industrializing Berlin, 2008.

AHLFELDT, G. / FEDDERSEN, A.: Determinants of Spatial Weights in Spatial Wage Equations: A Sensitivity Analysis, 2008.

MAENNIG, W. /ALLMERS, S.: South Africa 2010: Economic Scope and Limits, 2008.

MAENNIG, W. / WELLBROCK, C.-M.: Sozio-ökonomische Schätzungen Olympischer Medaillengewinne: Analyse-, Prognose- und Benchmarkmöglichkeiten, 2008. 


\section{Hamburg Contemporary Economic Discussions}

(Download: https://www.wiso.uni-hamburg.de/en/fachbereich-vwl/professuren/maennig/research/hceds.html)

19

18

17

16

15

14

13

12

11

10

09

08

07

06

AHLFELDT, G.: The Train has Left the Station: Real Estate Price Effects of Mainline Realignment in Berlin, 2008.

MAENNIG, W. / PORSCHE, M.: The Feel-good Effect at Mega Sport Events - Recommendations for Public and Private Administration Informed by the Experience of the FIFA World Cup 2006, 2008.

AHLFELDT, G. / MAENNIG, W.: Monumental Protection: Internal and External Price Effects, 2008.

FEDDERSEN, A. / GRÖTZINGER, A. / MAENNIG, W.: New Stadia and Regional Economic Development - Evidence from FIFA World Cup 2006 Stadia, 2008.

AHLFELDT, G. / FEDDERSEN, A.: Geography of a Sports Metropolis, 2007.

FEDDERSEN, A. / MAENNIG, W.: Arenas vs. Multifunctional Stadia - Which Do Spectators Prefer? 2007.

AHLFELDT, G.: A New Central Station for a Unified City: Predicting Impact on Property Prices for Urban Railway Network Extension, 2007.

AHLFELDT, G.: If Alonso was Right: Accessibility as Determinant for Attractiveness of Urban Location, 2007.

AHLFELDT, G., MAENNIG, W.: Assessing External Effects of City Airports: Land Values in Berlin, 2007.

MAENNIG, W.: One Year Later: A Re-Appraisal of the Economics of the 2006 Soccer World Cup, 2007.

HAGN, F. / MAENNIG, W.: Employment Effects of the World Cup 1974 in Germany.

HAGN, F. / MAENNIG W.: Labour Market Effects of the 2006 Soccer World Cup in Germany, 2007.

JASMAND, S. / MAENNIG, W.: Regional Income and Employment Effects of the 1972 Munich Olympic Summer Games, 2007.

DUST, L. / MAENNIG, W.: Shrinking and Growing Metropolitan Areas Asymmetric Real Estate Price Reactions? The Case of German Singlefamily Houses, 2007. 


\section{Hamburg Contemporary Economic Discussions}

(Download: https://www.wiso.uni-hamburg.de/en/fachbereich-vwl/professuren/maennig/research/hceds.html)

05

04

03

02

01

$04 / 2006$

$03 / 2006$

$02 / 2006$

$01 / 2006$

$04 / 2005$

$03 / 2005$

$02 / 2005$
HEYNE, M. / MAENNIG, W. / SUESSMUTH, B.: Mega-sporting Events as Experience Goods, 2007.

DU PLESSIS, S. / MAENNIG, W.: World Cup 2010: South African Economic Perspectives and Policy Challenges Informed by the Experience of Germany 2006, 2007.

AHLFELDT, G. / MAENNIG, W.: The Impact of Sports Arenas on Land Values: Evidence from Berlin, 2007.

FEDDERSEN, A. / MAENNIG, W. / ZIMMERMANN, P.: How to Win the Olympic Games - The Empirics of Key Success Factors of Olympic Bids, 2007.

AHLFELDT, G. / MAENNIG, W.: The Role of Architecture on Urban Revitalization: The Case of "Olympic Arenas" in Berlin-Prenzlauer Berg, 2007.

MAENNIG, W. / SCHWARTHOFF, F.: Stadium Architecture and Regional Economic Development: International Experience and the Plans of Durban, October 2006.

FEDDERSEN, A. / VÖPEL, H.: Staatliche Hilfen für Profifußballclubs in finanziellen Notlagen? - Die Kommunen im Konflikt zwischen Imageeffekten und Moral-Hazard-Problemen, September 2006.

FEDDERSEN, A.: Measuring Between-season Competitive Balance with Markov Chains, July 2006.

FEDDERSEN, A.: Economic Consequences of the UEFA Champions League for National Championships - The Case of Germany, May 2006.

BUETTNER, N. / MAENNIG, W. / MENSSEN, M.: Zur Ableitung einfacher Multiplikatoren für die Planung von Infrastrukturkosten anhand der Aufwendungen für Sportstätten - eine Untersuchung anhand der FußballWM 2006, May 2005.

SIEVERS, T.: A Vector-based Approach to Modeling Knowledge in Economics, February 2005.

SIEVERS, T.: Information-driven Clustering - An Alternative to the Knowledge Spillover Story, February 2005. 


\section{Hamburg Contemporary Economic Discussions}

(Download: https://www.wiso.uni-hamburg.de/en/fachbereich-vwl/professuren/maennig/research/hceds.html)

01/2005 FEDDERSEN, A. / MAENNIG, W.: Trends in Competitive Balance: Is there

Evidence for Growing Imbalance in Professional Sport Leagues? January 2005. 
